\title{
Accelerated thymus involution in magnesium-deficient rats is related to enhanced apoptosis and sensitivity to oxidative stress
}

\author{
Corinne Malpuech-Brugère ${ }^{1}$, Wojciech Nowacki ${ }^{2}$, Elyett Gueux ${ }^{1}$, Jan Kuryszko ${ }^{2}$, Edmond Rock ${ }^{1}$, \\ Yves Rayssiguier ${ }^{1}$ and Andrzej Mazur ${ }^{1 *}$ \\ ${ }^{1}$ Centre de Recherche en Nutrition Humaine d'Auvergne, Unité Maladies Métaboliques et Micronutriments, INRA, Theix, \\ 63122 St-Genès-Champanelle, France \\ ${ }^{2}$ Veterinary Faculty, Academy of Agriculture, 50375 Wroclaw, Poland
}

(Received 26 May 1998 - Revised 29 December 1998 - Accepted 21 January 1999)

\begin{abstract}
Experimental Mg deficiency leads to alterations in the immune response. Reduction of thymus weight and histological changes were previously observed in $\mathrm{Mg}$-deficient rats after several weeks on a deficient diet, suggesting that functions of this immune organ may be affected by $\mathrm{Mg}$ deficiency. More recently, changes in the immune system during early $\mathrm{Mg}$ deficiency were shown. Thus, in the present study we examined modifications in the thymus during the early stages of $\mathrm{Mg}$ deficiency in weanling rats. From our results, it appears that $\mathrm{Mg}$ deficiency accelerates thymus involution. The assessment of apoptosis (enumeration of apoptotic cells on the basis of morphological criteria and intranucleosomal degradation of genomic DNA) showed greater values in thymuses from $\mathrm{Mg}$-deficient rats as compared with controls. This was observed very early, since a significant difference was shown on the second day of deficiency, before reduced weight of thymus, which was recorded in the later period. These results indicate the relationship of accelerated thymus involution with an active process of cell death. Mg deficiency led to histological changes in the thymus. In the early stage of deficiency (second day) the presence of inflammatory cells was shown, suggesting that the inflammatory process was already occurring in the tissue studied. Later (eighth day) an increased proportion of epithelial reticular cells in the cortex was shown, indicating a remodelling process occurring in this period. Enhanced susceptibility to peroxidation also occurred very early during $\mathrm{Mg}$ deficiency. It may be hypothesized that disturbances in $\mathrm{Mg}$ status of short duration could have cellular effects with various deleterious consequences.
\end{abstract}

\section{Magnesium deficiency: Thymus involution: Apoptosis}

$\mathrm{Mg}$ plays an important role in the maintenance of host regulatory mechanisms in immunity. Dietary Mg deficiency in rodents, and especially in rats, causes inflammation (Weglicki et al. 1994; Rayssiguier et al. 1997) and leads to alterations in the immune response (Hass et al. 1980; Larvor, 1980; Galland, 1988; McCoy \& Kenney, 1995). Reduction of thymus weight and histological changes have previously been shown in $\mathrm{Mg}$-deficient rats after several weeks on a deficient diet (Stachura, 1971; Alcock et al. 1973; Dubiel-Bigaj, 1975; Stachura et al. 1975). This suggests that the functions of this immune organ may be affected by $\mathrm{Mg}$ deficiency.

The structure of the thymus varies markedly depending on the age and condition of the organism as a whole. This organ is larger in embryos and undergoes continuous involution throughout life. However, this process of normal or age-related involution may be altered by rapid changes of 'accidental involution' (Bloom \& Fawcett, 1968). Since the pioneering work of Selye in 1936 it has been known that, following noxious stimuli, stress results in thymic involution and lymphopenia. Recent data from our group and other workers (Weglicki et al. 1994; Rayssiguier et al. 1997) have shown early changes in the immune system during $\mathrm{Mg}$ deficiency. Therefore, in the present study we examined modifications occurring in the thymic gland during early stages of experimental $\mathrm{Mg}$ deficiency in young rats. Special attention was focused on the assessment of the extent of the apoptotic process, because of its crucial role in thymus involution. This cell death mechanism is involved in diverse biological processes during normal development and homeostasis in response to specific signals (Hale et al. 1996; Vaux \& Strasser, 1996). By this process appropriate cells are selectively eliminated during development. Apoptosis is also involved in many diseases and 
dysregulation of normal cell death can have profound consequences for pathophysiological processes. Since oxidative mechanisms are involved in the induction of apoptosis in some cell systems (Kroemer et al. 1995), sensitivity to oxidative stress was evaluated in thymuses of Mg-deficient animals in the present study.

\section{Materials and methods}

\section{Animals}

Male weanling Wistar rats (IFFA-CREDO, L'Arblesle, France), 3 weeks old and weighing about $60 \mathrm{~g}$, were randomly divided into Mg-deficient and control groups. The institution's guide for the care and use of laboratory animals was used. The rats were housed in wire-bottomed cages in a temperature-controlled room $\left(22^{\circ}\right)$ with a $12 \mathrm{~h}$ dark $(20.00-$ 08.00 hours) and $12 \mathrm{~h}$ light period. The animals were pairfed with the appropriate diets for $8 \mathrm{~d}$ using an automatic feeding apparatus. Distilled water was provided ad libitum. The synthetic diets contained $(\mathrm{g} / \mathrm{kg})$ : casein 200 , sucrose 650 , maize oil 50, alphacel (cellulose) 50, DL-methionine 3, choline bitartrate 2, modified AIN-76 mineral mix 35, AIN76A vitamin mix 10 (ICN Biomedicals, Orsay, France). $\mathrm{MgO}$ was omitted from the mineral mix in the Mg-deficient diet. The Mg concentrations of diets determined by flame atomic absorption spectrometric analysis (Perkin Elmer 400, Norwalk, CT, USA) were 35 and $980 \mathrm{mg} / \mathrm{kg}$ for deficient and control diets respectively.

After 2 and $8 \mathrm{~d}$ on the experimental diets the animals were anaesthetized with pentobarbital. Blood was collected by exsanguination via the abdominal aorta and heparinized plasma was obtained by centrifugation $(2000 \mathrm{~g}$, for $20 \mathrm{~min}$ at $4^{\circ}$ ). Thymuses were rapidly removed, weighed and immediately plunged into liquid $\mathrm{N}_{2}$ for peroxidation assays or treated for histological and immunochemical analyses as described.

\section{Analyses in the blood}

The total leucocyte count and the differential count for neutrophils, monocytes and lymphocytes were performed by routine techniques (Hudson \& Hay, 1989). Plasma Mg was determined by flame atomic absorption spectrometric analysis (Perkin Elmer 400) after dilution in $\mathrm{LaCl}_{3}$ solution containing $1 \mathrm{~g} \mathrm{La} / 1$. Plasma tumour necrosis factor- $\alpha$ (TNF$\alpha$ ) bioactivity was determined by using the fibroblast cell line L929a as previously described (Givalois et al. 1994). The cytotoxic activity of serial dilutions of plasma sample was compared with the activity of standard doses of human recombinant TNF- $\alpha$ (no. 88/532; National Institute for Biological Standards and Control, Herts., UK). Viability of the remaining adherent cells was measured at $540 \mathrm{~nm}$ in an MR 700 microplate reader (Dynatech Laboratories, Inc., Guernsey, Channel Islands, UK) after incubation with crystal violet $(5 \mathrm{~g} / \mathrm{l})$. TNF- $\alpha$ concentrations were also measured by using an ELISA kit, following the manufacturer's instructions (Genzyme Corp., Cambridge, MA, USA). Interleukin-6 bioassay was performed with the murine hybridoma cell line B9 as previously described (Givalois et al. 1994). Briefly, B9 cells were cultured in ninety-six-well microtitre plates with serial dilutions of test samples. The standard was human recombinant interleukin-6 (no. 89/548; National Institute for Biological Standards and Control), which was serially diluted. After $48 \mathrm{~h}$ incubation at $37^{\circ}$ in an incubator, $20 \mu \mathrm{l}$ 3-(4,5-dimethyltiazol-2-yl)-5-(3-carboxymethoxyphenyl)-2-(4-sulfophenyl)-2H-tetrazolium, inner salt $(2 \mathrm{mg} / \mathrm{ml})$ was added to each well in the presence of phenazine methosulfate and incubated for $2 \mathrm{~h}$ to determine cell proliferation. The water-soluble formazan product was quantified at $490 \mathrm{~nm}$ in a microplate reader (Dynatech).

\section{Histological analysis of the thymus}

For histological analysis, thymuses were fixed with buffered formalin $(40 \mathrm{ml} / \mathrm{l})$ and embedded in paraffin. Sections (5$7 \mu \mathrm{m}$ thick) were cut, picked up on slides, and stained with haematoxylin-eosin and alcian blue. The count of various cell types was performed on $1 \mathrm{~mm}^{2}$. The presence of cells with apoptotic morphology (nuclear and cytoplasmic condensation, modifications in nucleus and cell membrane morphology) was determined by examining $>600$ cells/ slide.

\section{Analysis of lymphocyte surface markers by flow cytometry}

Thymuses were aseptically removed from rats, briefly stored in Hanks' balanced salt solution (HBSS) modified (without phenol red) at $0^{\circ}$ and the cells were obtained by delacerating the tissue. They were suspended in $10 \mathrm{ml}$ HBSS (Bala \& Failla, 1993) and $3 \mathrm{ml}$ cell suspension, then dispensed on equal volume of Histopaque 1083 (Sigma, St Louis, MO, USA). Centrifugation was performed at $400 \mathrm{~g}$ for $30 \mathrm{~min}$ at room temperature. Mononuclear cells isolated by density gradient were washed with modified HBSS. For each cell preparation, cells were counted in a Malassez haemocytometer under a phase-contrast microscope, and their viability was determined by the Trypan-Blue exclusion method. Viability of freshly isolated cells exceeded $95 \%$. The procedure for immunolabelling of cell surface markers and subsequent analysis by flow cytometry has been described elsewhere (Bala \& Failla, 1993). Briefly, $50 \mu 1$ $2 \times 10^{7}$ mononuclear cells $/ \mathrm{ml}$ suspended in flow cytometry medium (phenol-red-free HBSS containing $10 \mathrm{ml}$ bovine serum albumin/l) were incubated with $1 \mathrm{mg}$ of one of the following murine anti-rat monoclonal antibodies: LCA (expressed on lymphoid and myeloid cells: lymphocytes, monocytes, polymorphonuclear cells), CD5 (expressed on T cells), CD4 (T cells, helper-inducer), CD8 (T cells, supressor-cytotoxic) and Thy1 (thymocytes) (GIBCO Life Technologies, Cergy-Pontoise, France) or with normal ascit (for the background). After incubation at $4^{\circ}$ for $45 \mathrm{~min}$, the cells were washed and incubated with $25 \mu 11 \%$ goat fluorescein isothiocyanate-labelled anti-mouse immunoglobulin $G$ (Organon Teknica Corporation, Durham, NC, USA) for $30 \mathrm{~min}$ at $4^{\circ}$. Unbound immunoglobulin $\mathrm{G}$ was removed by washing and the cells were suspended in $200 \mu$ l flow cytometry medium; flow cytometry was performed with an Epics Profile I (Coulter Electronics Inc., Hialeah, FL, USA) unit equipped with an argon laser at $488 \mathrm{~nm}$ and run at $15 \mathrm{~mW}$. The flow cytometer was gated on viable mononuclear cells to exclude cell debris and erythrocytes. 


\section{Detection of DNA fragmentation in thymuses}

The extent of apoptosis was evaluated by the measurement of DNA fragmentation. This was assessed by quantification of cytosolic oligonucleosome-bound DNA by using the Cell Death Detection ELISA kit (Boehringer Mannheim, Mannheim, Germany). Thymuses were treated with three strokes of a Polytron homogenizer. The $200 \mathrm{~g} / \mathrm{l}$ homogenate was made with the following buffer: $50 \mathrm{mM}$-phosphate, $120 \mathrm{mM}$ $\mathrm{NaCl}$, and $10 \mathrm{mM}$-EDTA, $\mathrm{pH} 7.4$ and then centrifuged at $13000 \mathrm{~g}$ for $20 \mathrm{~min}$ at $4^{\circ}$. The supernatant fraction was then diluted 200-fold and used as the antigen source for the immunoassay. This assay is based on the quantitative sandwich ELISA principle using mouse monoclonal antibodies directed against histones (coating antibody) and DNA (peroxidase-labelled antibody) respectively. The amount of peroxidase retained in the immunocomplex is determined photometrically with ABTS $^{\circledR}\left(2,2^{\prime}\right.$-azino-di-(3ethylbenzthiazoline sulfonate)) as a substrate. This allows the specific determination of mono-and oligonucleosomes in the cytoplasmic fraction of cell lysates. The DNA fragmentation pattern (DNA laddering) was also assessed by agarose gel electrophoresis. For this purpose, thymus cell suspensions were pelleted by centrifugation at $800 \mathrm{~g}$ for $5 \mathrm{~min}$. Then, the cells were digested with lysis buffer (10 mM-Tris-HCl, $\mathrm{pH} 8.0,25$ mM-EDTA, $5 \mathrm{~g}$ SDS/1, $50 \mu \mathrm{g}$ proteinase $\mathrm{K} / \mathrm{ml}, 20 \mu \mathrm{g}$ ribonuclease $/ \mathrm{ml}$ ) at $37^{\circ}$ overnight. The DNA samples were extracted twice with phenolchloroform-isoamyl alcohol (25:24:1, by vol.) and precipitated with $2.5 \mathrm{M}$-sodium acetate and ethanol at $-20^{\circ}$ overnight. The pellets were re-suspended in buffer $(10 \mathrm{mM}-$ Tris, 1 mM-EDTA, pH 7.4) and subjected to electrophoresis on an $18 \mathrm{~g} / \mathrm{l}$ agarose gel. The DNA in the gel was visualized under u.v. light after ethidium bromide staining (Li et al. 1997).

\section{Measurements of thiobarbituric acid-reactive substances in thymus homogenates}

Tissue homogenates were prepared on ice in the ratio $1 \mathrm{~g}$ wet tissue : $9 \mathrm{ml} 154 \mathrm{mM}-\mathrm{KCl}$ using a polytron homogenizer. Thiobarbituric acid-reactive substances were determined in tissue homogenates after lipid peroxidation induced with $\mathrm{FeSO}_{4}(10 \mu \mathrm{M})$-ascorbate $(250 \mu \mathrm{M})$ for $30 \mathrm{~min}$ in a $37^{\circ}$ water bath, using a malondialdehyde standard prepared from 1,1,3,3-tetraethoxypropane (Ohkawa et al. 1979).

\section{Statistical analyses}

Results are expressed as means with their standard errors. The statistical significance of differences between means was assessed by Student' $t$ test. Differences were considered statistically significant at $P<0.05$.

\section{Results}

After $8 \mathrm{~d}$ on the $\mathrm{Mg}$-deficient diets, the animals presented classical signs of inflammation described during this deficiency, i.e. hyperaemia, splenomegaly and leucocytosis (mainly polymorphonuclear cells; Table 1). The first clinical symptoms of inflammation appeared after about $4 \mathrm{~d}$ on the Mg-deficient diet. Plasma analyses on the eighth day of deficiency showed a significant increase in plasma interleukin- 6 concentration when compared with controls, however TNF- $\alpha$ was below detectable values $(<2.5 \mathrm{pg} / \mathrm{ml})$ in both groups (Table 1). Clinical symptoms and plasma variables related to inflammation were not discernible on the second day of deficiency (results not shown). However, plasma $\mathrm{Mg}$ decreased early on the Mg-deficient diet; on the second day of deficiency the $\mathrm{Mg}$ concentration was about half that of controls. After $8 \mathrm{~d}$ plasma $\mathrm{Mg}$ in deficient rats was between $0 \cdot 1$ and $0.2 \mathrm{mmol} / \mathrm{l}$ (Fig. 1).

After $8 \mathrm{~d}$ on the experimental diets, the mean thymus weight of deficient rats was lower than that of controls (Fig. 1). Histological modifications were found in the thymuses of deficient rats in both periods studied (Fig. 2). The medulla presented an increased proportion of macrophages and neutrophils on the second day of deficiency. In the cortex an increased proportion of epithelial reticular cells was shown after $8 \mathrm{~d}$ on the deficient diet. The assessment of morphological alterations showed a greater proportion of apoptotic cells among lymphocytes and reticular cells in thymus of $\mathrm{Mg}$-deficient rats as compared with controls (Fig. 3), especially after $2 \mathrm{~d}$ of deficiency. Lymphocyte populations in the thymus did not show significant changes after $8 \mathrm{~d}$ of deficiency (Table 2).

The detection of histone-associated DNA fragments, demonstrating the intranucleosomal degradation of genomic DNA, showed significantly greater values in thymuses from Mg-deficient than control rats after $2 \mathrm{~d}$ on the experimental diets (34\% increase; Fig. 1). Similarly, the tendency to higher values was also observed after $8 \mathrm{~d}$ of deficiency. In both groups, values obtained were greater after $2 \mathrm{~d}$ than after $8 \mathrm{~d}$ after weaning. Despite the significant increase in the level of histone-associated DNA fragments in $\mathrm{Mg}$-deficient rats, we were unable to detect DNA fragmentation by electrophoresis and ethidium bromide staining.

In both periods studied, greater malondialdehyde production after induction of oxidation with $\mathrm{FeSO}_{4}$-ascorbate was observed in thymus homogenates of $\mathrm{Mg}$-deficient rats (about 2-fold after $2 \mathrm{~d}$ of deficiency and 3-fold and after $8 \mathrm{~d}$ ) as compared with controls (Fig. 1).

\section{Discussion}

In the present work we chose to study rats after $2 \mathrm{~d}$ on a $\mathrm{Mg}$ deficient diet to assess if early modifications occurred in the

Table 1. Body weight and inflammatory variables in the blood of control and magnesium-deficient rats after $8 \mathrm{~d}$ on the experimental diets* $^{*}$

(Mean values with their standard errors for twelve animals per group)

\begin{tabular}{|c|c|c|c|c|c|}
\hline & \multicolumn{2}{|c|}{ Control } & \multicolumn{2}{|c|}{ Mg-deficient } & \multirow[b]{2}{*}{$P+$} \\
\hline & Mean & SE & Mean & SE & \\
\hline Body weight (g) & 94 & 2 & 91 & 1 & NS \\
\hline Leucocytes $\left(10^{6} / \mathrm{ml}\right)$ & 4.4 & 0.5 & 8.0 & 1.2 & $<0.05$ \\
\hline PMN cells $\left(10^{6} / \mathrm{ml}\right)^{\prime}$ & 0.8 & 0.1 & 3.0 & 0.7 & $<0.01$ \\
\hline Plasma TNF- $\alpha(\mathrm{pg} / \mathrm{ml})$ & ND & & ND & & \\
\hline Plasma IL-6 (pg/ml) & 39 & 2 & 98 & 12 & $<0.001$ \\
\hline
\end{tabular}

PMN, polymorphonuclear; TNF- $\alpha$, tumour necrosis factor- $\alpha$; IL-6, interleukin-6; $\mathrm{ND}$, not detectable $(<2.5 \mathrm{pg} / \mathrm{ml})$.

${ }^{*}$ For details of diets and procedures, see pp. 406-407.

† Assessed by Student's $t$ test. 

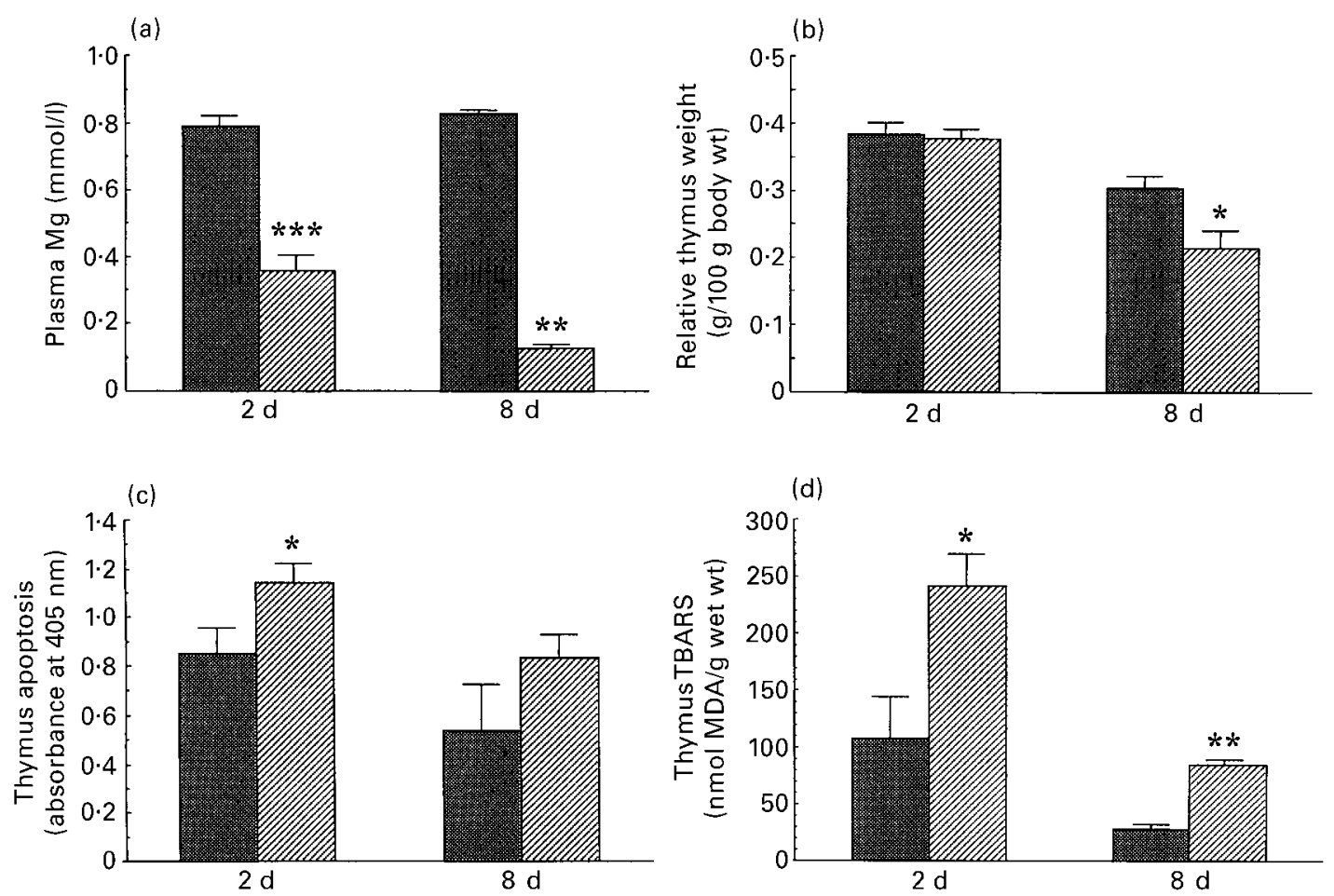

Fig. 1. (a) Plasma magnesium concentration, (b) relative thymus weight, (c) apoptosis in the thymus and (d) thiobarbituric acid reactive substances (TBARS) in the thymus of rats after 2 and $8 \mathrm{~d}$ on a control diet (网) or a magnesium-deficient diet (何). Values are means of six animals per group, with their standard errors represented by vertical bars. Mean values were significantly different from those for the corresponding control group: ${ }^{*} P<0.05,{ }^{* *} P<0.01,{ }^{* * *} P<0.001$. MDA, malondialdehyde.

thymus at the beginning of deficiency and after $8 \mathrm{~d}$, because of established symptoms of inflammation at this stage of deficiency (Rayssiguier et al. 1997). Because thymus involution is rapid during early life we performed our studies on young rats in which $\mathrm{Mg}$ deficiency was induced by a deficient diet immediately after weaning. From our results it appears that $\mathrm{Mg}$ deficiency accelerates thymus involution. This observation is in agreement with previous studies that have shown reduced thymus weight during $\mathrm{Mg}$ deficiency (Stachura, 1971; Alcock et al. 1973; Dubiel-Bigaj, 1975; Stachura et al. 1975). However, these previous results were obtained after weeks rather than days of deficiency. Our observation, made after 1 week of deficiency, shows that there is a rapid effect on thymus involution. The enumeration of apoptotic cells on the basis of morphological criteria and the assessment of intranucleosomal degradation of genomic DNA showed greater values in thymuses from Mg-deficient rats. This was observed very early during deficiency, since significant differences were noticed as early as the second day of deficiency, even before the decrease of thymus weight recorded in the later period. These results demonstrate the relationship of accelerated thymus involution with an active process of cell death (apoptosis) during $\mathrm{Mg}$ deficiency. However, we were unable to detect DNA fragmentation by electrophoresis and ethidium bromide staining. This could be explained by the fact that although in some experimental models apoptotic DNA fragmentation is easily detected, in other cases apoptosis may be found in only a limited number of cells. In the latter case, conventional ethidium bromide staining of DNA may not be sufficiently sensitive to reveal a classical DNA ladder.

$\mathrm{Mg}$ deficiency led to histological changes in the thymus. Of interest was the presence of inflammatory cells in the early stages of deficiency (second day), suggesting that the inflammatory process had already occurred in the tissue studied. At the later stage ( $8 \mathrm{~d}$ ) an increased proportion of epithelial reticular cells in the cortex was shown indicating the remodelling process which occurs in this period. A previous study by Stachura (1971) found a similar observation during chronic $\mathrm{Mg}$ deficiency i.e. an increased number of epithelial reticular cells accompanied by thymocyte depletion. However, in the present study, the numbers of thymocytes and thymocyte populations were not affected by $\mathrm{Mg}$ deficiency.

Interestingly, we showed that $\mathrm{Mg}$ deficiency results in greater susceptibility of the thymus to lipid peroxidation. This finding is in agreement with previous observations made in various tissues from $\mathrm{Mg}$-deficient animals by others (Freedman et al. 1990; Günther et al. 1992; Weglicki et al. 1993) and by us (Rayssiguier et al. 1993; Rock et al. 1995). However, the new finding here was that the thymus peroxidation is significantly increased at the beginning of $\mathrm{Mg}$ deficiency. The nature and origin of these modifications should be defined. Oxidative stress has been suggested as a mediator in the apoptotic process (Vaux \& Strasser, 1996). Of interest is the observation of inflammatory cells in the thymus during early deficiency. This may be considered as the consequence of tissue damage, however, these cells could also enhance oxidative damage since they produce 

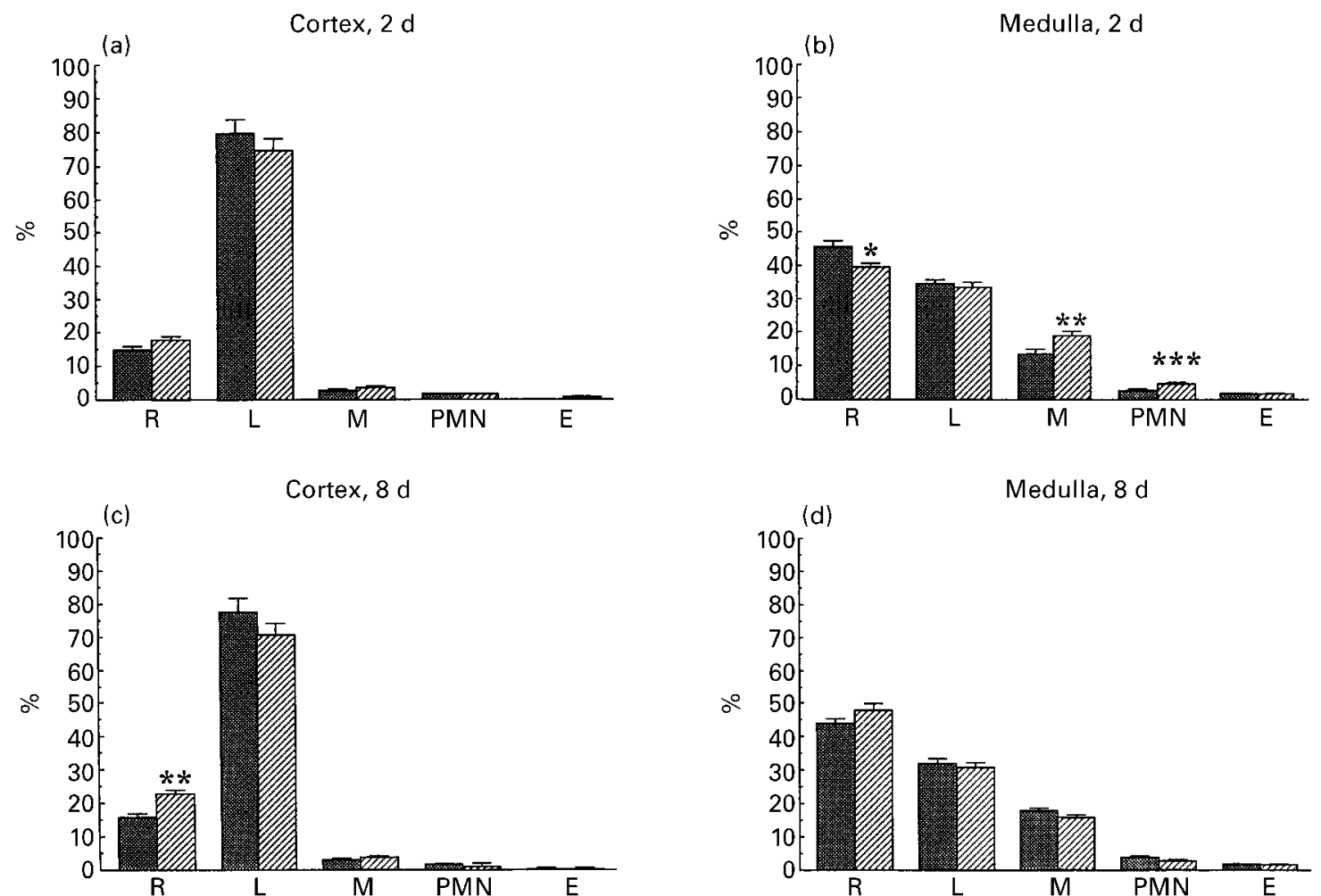

Fig. 2. Percentage distribution of various cell populations in the cortex $(a, c)$ and medulla $(b, d)$ of thymuses from rats after $2 d(a, b)$ or $8 d(c, d)$ on a control diet (网) or a magnesium-deficient diet (何). R, reticular cell; L, lymphocyte; M, macrophage; PMN, polymorphonuclear leucocyte; E, eosinophil. Values are means of six animals per group, with their standard errors represented by vertical bars. Mean values were significantly different from those for the corresponding control group: ${ }^{*} P<0.05,{ }^{* \star} P<0.01,{ }^{\star \star *} P<0.001$.

free radicals. On the other hand, the rapid increase of the sensitivity to peroxidation suggests very early depletion of antioxidant defences in the thymus of Mg-deficient rats.

The modified immune response in Mg-deficient animals has been previously reported and this may have consequences for health in later life in young animals who are Mg-deficient (Hass et al. 1980; Larvor, 1980; Galland, 1988; McCoy \& Kenney, 1995). It is suggested that modifications in the thymus may contribute to the harmful consequences of $\mathrm{Mg}$ deficiency for immunity. One of the reasons for this may be the thymocyte depletion that occurs in chronic Mg deficiency (Stachura, 1971) which can lead to lymphopenia. Other studies have shown that long-term (2 months) $\mathrm{Mg}$ deficiency results in reduced thymus weight in many rats, but others have shown thymus enlargement and lymphomas (malignant lymphosarcomas) (Bois, 1964; Alcock et al. 1973; Günther et al. 1984). These observations support the concept that $\mathrm{Mg}$ is important in oncogenesis (Walker, 1986). The intracellular signals involved in induction of apoptosis are often involved in promotion of proliferation or differentiation in other cellular contexts (Hale et al. 1996). It has been suggested (Khan et al. 1996) that although mature lymphocytes proliferate when they are subjected to immune stimuli, immature lymphocytes instead undergo apoptosis, when stimulated in the same manner.

The precise mechanism by which $\mathrm{Mg}$ deficiency enhances the apoptotic process in the thymus remain to be determined. A cell will undergo apoptosis as a result of information received from its environment interpreted in the context of internal information, such as its type, state of (a)

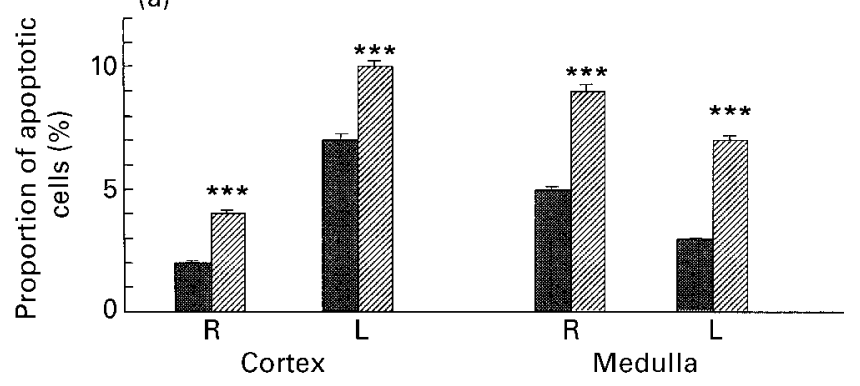

(b)

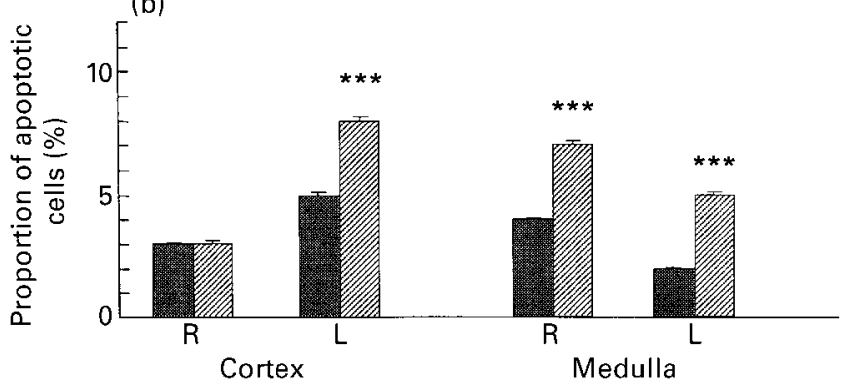

Fig. 3. Percentage of apoptotic cells, evaluated on the basis of morphological criteria, among lymphocytes $(L)$ and reticulocytes $(R)$ from thymuses of rats after (a) $2 \mathrm{~d}$ and (b) $8 \mathrm{~d}$ on a control diet ( $\otimes$ ) or a

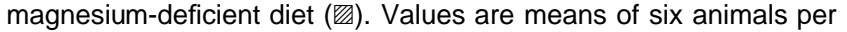
group, with their standard errors represented by vertical bars. Mean values were significantly different from those for the corresponding control group: ${ }^{* \star *} P<0.001$. 
Table 2. Lymphocyte number and populations in the thymus of control and magnesium-deficient rats after $8 \mathrm{~d}$ on the experimental diets* $^{*}$

(Mean values with their standard errors for seven animals per group)

\begin{tabular}{lcrlll}
\hline & \multicolumn{2}{c}{ Control } & & \multicolumn{2}{c}{ Mg-deficient } \\
\cline { 2 - 3 } \cline { 6 - 6 } & Mean & SE & & Mean & SE \\
\hline Number of cells (/g thymus) & 3098 & 172 & & 3127 & 227 \\
Populations (\% positive cells) & & & & \\
LCA & 92.3 & 0.4 & & 96.3 & 0.3 \\
Thy1 & 97.6 & 0.8 & & 95.1 & 0.6 \\
CD5 & 72.0 & 3.0 & & 67.2 & 1.3 \\
CD4 & 93.8 & 1.7 & & 92.8 & 1.5 \\
CD8 & 85.1 & 1.6 & & 86.9 & 2.4 \\
\hline
\end{tabular}

*For details of diets and procedures, see pp. 406-407.

maturity and developmental history. The external signal triggering apoptosis could be, for example, the appearance or disappearance of hormones or cytokines. During $\mathrm{Mg}$ deficiency modifications in cytokine (Weglicki et al. 1993; Rayssiguier et al. 1997) and hormone profiles (Seelig, 1980) were reported. However, it appears that this process is not related to TNF- $\alpha$ because we did not detect measurable levels of this cytokine. Ca entry into cells appears to be a critical early event in apoptosis (McConkey et al. 1989). The rise in intracellular $\mathrm{Ca}^{2+}$ concentration elicited by low extracellular $\mathrm{Mg}^{2+}$ could be a trigger of endonucleolytic processes leading to apoptosis. $\mathrm{Mg}$ is considered as the natural $\mathrm{Ca}$ antagonist and it has previously been shown in various types of cells that withdrawal of extracellular $\mathrm{Mg}^{2+}$ increases either intracellular $\mathrm{Ca}^{2+}$ or Cadependent stimuli (Zhang et al. 1992; Noguera \& D’Ocon, 1993; Mooren et al. 1994; Vierling \& Stampfl, 1994; Zhu et al. 1995; Zhang et al. 1996). The increase of intracellular $\mathrm{Ca}^{2+}$ and changes in its intracellular distribution have been shown in thymocytes during chronic $\mathrm{Mg}$ deficiency (Günther et al. 1984). This may be considered as the main hypothesis for the observed effect in the thymus and needs to be confirmed.

In summary, this study shows that $\mathrm{Mg}$ deficiency causes accelerated thymus involution associated with histological modifications and the active process of cell death. In the light of these observations, it may be assumed that disturbances in $\mathrm{Mg}$ status of short duration should have cellular consequences in the immune system on controlling processes such as multiplication, differentiation and cell death, which may have various deleterious consequences.

\section{Acknowledgements}

The authors would like to thank Dr J. Chassagne for help in flow cytometer analyses and Dr J. Dornand for help in cytokine measurements. This work was presented in part at the 8th International Symposium on Magnesium, Heraklion, Greece, October 1997.

\section{References}

Alcock NW, Shils ME, Lieberman PH \& Erlandson RA (1973) Thymic changes in the magnesium-depleted rat. Cancer Research 33, 2196-2204.
Bala S \& Failla ML (1993) Copper repletion restores the number and function of CD4 cells in copper-deficient rats. Journal of Nutrition 123, 991-996.

Bloom W \& Fawcett DW (1968) A Textbook of Histology. Philadelphia, PA: WB Saunders Company.

Bois $\mathrm{P}$ (1964) Tumour of the thymus in magnesium deficient rats. Nature 204, 1316.

Dubiel-Bigaj M (1975) Badania ultrastrukturalne grasicy szczura we wczesnych okresach niedoboru magnezu (Ultrastructural studies of rat thymus in early stages of magnesium deficiency). Patologia Polska 26, 359-367.

Freedman AM, Atrakchi AH, Cassidy MM \& Weglicki WB (1990) Magnesium deficiency-induced cardiomyopathy: protection by vitamin E. Biochemical and Biophysical Research Communications 170, 1102-1106.

Galland G (1988) Magnesium and immune function: an overview. Magnesium 7, 290-299.

Givalois L, Dornand J, Mekaouche M, Solier MD, Bristow AF, Ixart G, Siaud P, Assenmacher I \& Barbanel G (1994) Temporal cascade of plasma level surges in ACTH, corticosterone, and cytokines in endotoxin-challenged rats. American Journal of Physiology 267, R164-R170.

Günther T, Vormann J, Höllriegl V, Disch G \& Classen AH (1992) Role of lipid peroxidation and vitamin $\mathrm{E}$ in magnesium deficiency. Magnesium Bulletin 14, 57-66.

Günther T, Vormann J, Merker HJ, Averdunk R, Peter HW \& Wonigeit K (1984) Membrane alterations in magnesiumdeficiency-induced malignant $\mathrm{T}$ cell lymphoma. Magnesium 3, 29-37.

Hale AJ, Smith CA, Sutherland LC, Stoneman VEA, Lonhthorne VL, Culhane AC \& Williams GT (1996) Apoptosis: molecular regulation of cell death. European Journal of Biochemistry 236 , $1-26$.

Hass GM, McCreary PA, Laing GH \& Galt RM (1980) Lymphoproliferative and immunologic aspects of magnesium deficiency. In Magnesium in Health and Disease, pp. 187-200 [M Cantin and MS Seelig, editors]. New York, NY: Spectrum.

Hudson L \& Hay FC (1989) The lymphocyte: its role and function. In Practical Immunology, 3rd ed., pp. 86-126. Oxford: Blackwell Scientific Publications.

Khan AA, Soloski MJ, Sharp AH, Schilling G, Sabatini DM, Li SH, Ross CA \& Snyder SH (1996) Lymphocyte apoptosis: mediation by increased type 3 inositol 1,4,5-triphosphate receptor. Science 273, 503-507.

Kroemer G, Petit P, Zamzami N, Vayssière JL \& Mignotte B (1995) The biochemistry of programmed cell death. FASEB Journal 9, 1277-1287.

Larvor P (1980) Magnesium, humoral immunity, and allergy. In Magnesium in Health and Disease, pp. 201-204 [M Cantin and MS Seelig, editors]. New York, NY: Spectrum.

Li PF, Dietz R \& von Harsdorf R (1997) Reactive oxygen species induce apoptosis of vascular smooth muscle cell. FEBS Letters 464, 249-252.

McConkey DJ, Hartzell P, Nicotera P \& Orrenius S (1989) Calcium-activated DNA fragmentation kills immature thymocytes. FASEB Journal 3, 1843-1849.

McCoy H \& Kenney MA (1995) Magnesium and immune function. In Handbook of Metal-Ligand Interactions in Biological Fluids, pp. 871-885 [G Berthon, editor]. New York, NY: M. Dekker, Inc.

Mooren FC, Stoll R, Spyrou E, Beil W \& Domschke W (1994) Stimulus-secretion coupling in rat parietal cells is affected by extracellular magnesium. Biochemical and Biophysical Research Communications 204, 512-518.

Noguera MA \& D'Ocon MP (1993) Modulatory role of magnesium on the contractile response of rat aorta to several agonists in normal and calcium-free medium. Journal of Pharmacy and Pharmacology 45, 697-700. 
Ohkawa H, Ohishi N \& Yagi K (1979) Assay for lipid peroxides in animal tissues by thiobarbituric acid reaction. Analytical Biochemistry 95, 351-358.

Rayssiguier Y, Gueux E, Bussière L, Durlach J \& Mazur A (1993) Dietary magnesium affects susceptibility of lipoproteins and tissues to peroxidation in rats. Journal of the American College of Nutrition 12, 133-137.

Rayssiguier Y, Malpuech C, Nowacki W, Rock E, Gueux E \& Mazur A (1997) Inflammatory response in magnesium deficiency. In Advances in Magnesium Research: Magnesium in Cardiology, pp. 415-421 [R Smetana, editor]. London: John Libbey.

Rock E, Astier C, Lab C, Vignon X, Gueux E, Motta C \& Rayssiguier Y (1995) Dietary magnesium deficiency in rats enhances free radical production in skeletal muscle. Journal of Nutrition 125, 1205-1210.

Seelig MS (1980) Magnesium deficiency in the pathogenesis of disease. In Topics in Bone and Mineral Disorders, p. 488 [LV Avioli, editor]. New York, NY: Plenum.

Stachura J (1971) Badania morfologiczne w niedoborze i nadmiarze magnezu u szczura (Morphological studies during deficiency and excess of magnesium in the rat). Patologia Polska 22, 41-53.

Stachura J, Turowski G \& Bigaj M (1975) Poziom ‘tymozyny' we krwi szczurow z niedoborem magnezu (Level of 'thymosin' in the blood of rats with magnesium deficiency). Patologia Polska 26, 369-378.
Vaux DL \& Strasser A (1996) The molecular biology of apoptosis. Proceedings of the National Academy of Sciences USA 93, 2239-2244.

Vierling W \& Stampfl A (1994) Magnesium-dependent calcium efflux in mammalian heart muscle. Cell Calcium 15, 175-182.

Walker GM (1986) Magnesium and cell cycle control: an update. Magnesium 5, 9-23.

Weglicki WB, Stafford RE, Freedman AM, Cassidy MM \& Phillips TM (1993) Modulation of cytokines and myocardial lesions by vitamin $\mathrm{E}$ and chloroquine in a magnesium-deficient rat model. American Journal of Physiology 264, C723-C726.

Weglicki WB, Phillips TM, Mak IT, Cassidy MM, Dickens BF, Stafford R \& Kramer JH (1994) Cytokines, neuropeptides, and reperfusion injury during magnesium deficiency. Annals of the New York Academy of Sciences 723, 246-257.

Zhang A, Chen TP \& Altura BM (1992) Magnesium regulates intracellular free ionized calcium concentration and cell geometry in vascular smooth muscle cells. Biochimica et Biophysica Acta 1134, 25-29.

Zhang A, Fan SH, Chen TP, Altura BT, Wong RK \& Altura BM (1996) Extracellular $\mathrm{Mg}^{2+}$ modulates intracellular $\mathrm{Ca}^{2+}$ in acutely isolated hippocampal CA1 pyramidal cells of the guinea-pig. Brain Research 728, 204-208.

Zhu Z, Tepel M, Spieker C \& Zidek W (1995) Effect of extracellular $\mathrm{Mg}^{2+}$ concentration on agonist-induced cytosolic free $\mathrm{Ca}^{2+}$ transients. Biochimica et Biophysica Acta 1265, 8992. 